\title{
History of Science: Politicizing a Discipline
}

\author{
John Staddon
}

History of science is a relatively new field. The original emphasis, in the works of George Sarton, Gerald Holton, and Thomas Kuhn, for example, was on natural science, but today it has become more personal: biographies and biographical sketches abound, and social influences are promoted over the purely intellectual force of scientific findings. Political issues such as feminism play an increasing role. A colorful French nouveau philosophe, Bruno Latour, has become a leading figure in the new sociological field of "science studies," in which social (political incentives) and personal (expertise, gender) factors dominate. Science is on its way to becoming a social construct.

Recent books illustrate three trends: a retreat from political neutrality; de-emphasis of the "truth" (however assessed) of scientific claims as a source of their acceptance; and the desire for a good story, preferably a capitalist plot.

\section{The First Cause}

Historians have always been targets of criticism: bias, omissions, inaccuracies, fabrications, insinuations, and just a bad attitude have been charges aimed at even the most eminent. Edward Gibbon, author of the incomparable History of the Decline and Fall of the Roman Empire (1782) was not immune. He was accused of disrespecting Christianity. For example, in this passage:

Our curiosity is naturally prompted to inquire by what means the Christian faith obtained so remarkable a victory over the established religions of the earth. To this inquiry, an obvious but satisfactory answer may be returned; that 
it was owing to the convincing evidence of the doctrine itself, and to the ruling providence of its great Author. But as truth and reason seldom find so favorable a reception in the world ... we may still be permitted . . to ask, not indeed what were the first, but what were the secondary causes of the rapid growth of the Christian church ...

A modern reader will surely see Gibbon's obeisance to Christianity as graceful and necessary, though possibly insincere. But Gibbon had a point about proof. Philosopher David Hume perhaps convinced him that the facts of science are provable but the facts of religion for the most part are not. They are matters of faith, not science,

History of science is different. Science's whole existence depends ultimately upon convincing evidence. We believe in the facts of science because they have passed our tests. These proofs surely are, in Gibbon's words, the first causes for the rapid growth of science. It follows that a prerequisite for any historian of science is to understand the science. In this respect, some contemporary historians of science are not doing well.

\section{Darwin and the (Political) History of Science}

Sneers have been directed at Charles Darwin in influential modern histories. For example, there is some controversy about Darwin's reaction to Alfred Russel Wallace's scooping his discovery of evolution by natural selection. In 1858, Wallace, a young naturalist who had corresponded previously with Darwin, sent him a short paper. He asked Darwin to send the piece to Darwin's friend and mentor, geologist Charles Lyell. Wallace's paper reached the same conclusion Darwin had been buttressing with tireless research for the previous twenty years. Darwin was devastated. Some years earlier he had shown an essay describing natural selection to several colleagues, so there is no doubt that he had the idea first, not to mention a pile of data and arguments to support it and refute many possible objections.

Darwin had delayed publication for several reasons. Possibly he thought the anti-religious implications of evolution too inflammatory to publish without overwhelming support-Robert Bridges in his popular (but anonymous) Vestiges of the Natural History of Creation (1844) had achieved the kind of notoriety that 
was anathema to Darwin. More likely he was simply conscientious; he wanted to get it right before going public.

Wallace did not mention publication in his letter, but this is what Darwin wrote to Lyell: He would "of course, at once write and offer to send [Wallace's paper] to any journal." Yet “all my originality, whatever it may amount to, will be smashed ... I should be extremely glad now to publish a sketch of my general views in about dozen pages or so. But cannot persuade myself that I can do so honourably." These are not the words of an arrogant or dishonest man. Years later, Wallace was perfectly happy at the way Darwin had treated him and named his book on the topic Darwinism.

Yet, here is the sneer. We learn from Adrian Desmond and James Moore's 808 page Darwin: The Life of a Tormented Evolutionist (1991) that "[i]rony and ambiguity shrouded Darwin as no other eminent Victorian.” Desmond and Moore go on:

[Darwin] hunted with the clergy and ran with radical hounds; he was a paternalist full of noblesse oblige [a bad thing, apparently], sensitive, mollycoddled [despite heroic actions during the Beagle voyage that got a channel named after him], cut off from wage-labour and competition [could he have done so much science otherwise?], who unleashed a bloody struggle for existence [blaming the messenger?]; a hard-core scientist addicted to quackery , , , [he tried odd-sounding remedies for a medical condition that had no cure at that time]. ${ }^{2}$

Polite inquiries of a scientific opponent, the American Alexander Agassiz, are labeled “pickpocketing." Describing Darwin's interaction with pigeonfanciers, they write: “His kindly paternalism gave their backyard hobby a certain cachet. But to the end he remained imperturbably a gent among working fanciers.” Moreover, Darwin dissimulated. To his cousin Fox on the mutability of species Darwin wrote, "I mean with my utmost power to give all arguments \& facts on both sides.” Desmond and Moore know better: “Balance and doubt were a public mask. Despite appearances, he knew exactly what he was doing." These eminent historians of science discern dishonorable motives

1 Quoted in Janet Browne's excellent Darwin: The Power of Place (Alfred Knopf, 2002).

2 Possibly lactose intolerance: A.K. Campbell, S. B. Matthews, "Darwin's illness revealed," Postgraduate Medical Journal 2005). 
even in Darwin's most transparently decent actions. It seems to be his uppermiddle-class origins they particularly dislike, irrelevant though these should be to any assessment of his scientific achievements.

Wallace and Darwin viewed natural selection a bit differently. According to Desmond and Moore, Darwin provided what his supporter T. H. Huxley wanted, "a new competitive, capitalist sanction in place of Anglican Oxbridge paternalism.” Darwinian evolution was a metaphor for industrial capitalism. “Nature was a self-improving 'workshop,' evolution the dynamic economy of life. The creation of wealth and the production of species obeyed similar laws." Darwin's views are hardly surprising, since he "was a heavy investor in industry," not to mention family connections to the industrial Wedgwoods. Never mind; true or false, Darwinian natural selection is just capitalism by another name.

Wallace, on the other hand, was self-employed, more interested in cooperation than competition and a "self-taught socialist." "Wallace's naturally selected group morality was leading society in a very un-Darwinian direction [not that Darwin ever speculated about society].” Wallace also believed that humanity, because of language and intellect, was special. Wallace believed in the inevitability of evolutionary progress. Darwin did not; contemporary evolutionary biology also does not.

Needless to say, Desmond and Moore do not think that Darwin treated Wallace well. He should have seen from their earliest correspondence that Wallace was on to natural selection: "He did not really catch Wallace's drift." Darwin should just have bowed out, apparently. This gross misapprehension has made it into popular writing, even of usually perceptive and always entertaining Tom Wolfe. ${ }^{3}$

The authors seem to trace Darwin's ideas not to his own genius and the mountains of data he gathered, but to his class, his upbringing, and his position in society. How much more likely is it that their own biases arise from a like cause? Previous coverage of Darwin "served a purpose a century ago in securing Darwin's immortality ... But today's needs are different ... We want to understand how his theories and strategies were embedded in a reforming Whig society.” Desmond and Moore are determined to tie Darwin's behavior to social issues rather than to his curiosity and love of nature, puzzling over rocks and

3 Tom Wolfe, The Kingdom of Speech, (Little, Brown, 2016). See also John Staddon, "An Open Letter to Tom Wolfe," Psychology Today, October 11, 2016. 
atolls, barnacles and beetles. The man's intellectual independence, his ability to ponder problems invisible to many others, is lost in Desmond and Moore's account. Society, social movements, social agitations-social is the thing. Yet all admit that Darwin was for most of his life a recluse. He communicated largely by letter and largely about biology. He wrote almost nothing about society. He was neither a sociologist nor a political scientist; he was above all a biologist. His inspiration was from nature, not society. This is a conclusion that Desmond and Moore seem unwilling even to entertain, much less accept.

Desmond and Moore's book is long and copiously referenced. They (unlike some others I will mention) obviously understand the science. But they give little weight to it. Instead their view of the man and his achievements is suffused with a sneering politically tinged tone that disparages Darwin and devalues his scientific contribution. Darwin was just a predictable product of his time and place. No room for talent or even luck. No room for the verifiable truth of the man's ideas. The book is not a history of science so much as politics by other means.

\section{First, understand}

Nancy MacLean is the William H. Chafe Professor of History and Public Policy at Duke University. She has written a book whose central figure is a soft-spoken Southern economist, winner of the 1986 Nobel prize in economics, James McGill Buchanan. Michael Munger, a Duke colleague and expert in public choice, Buchanan's field, calls it a "remarkable book," albeit "speculative historical fiction.” A strong charge, but amply documented in Munger's long review. ${ }^{4}$

Democracy in Chains (2017) is about threats to American democracy. ${ }^{5}$ It is written in a lively, who-dunnit fashion in which Buchanan is the evil conspirator at the heart of the plot. Buchanan died conveniently, it turns out, in 2013, allowing MacLean to attribute motives to him without danger of rebuttal and to find an un-curated and uncensored trove of Buchanan's papers in a house at George Mason University.

4 Michael C. Munger, "On the origins and goals of public choice: constitutional conspiracy?" The Independent Review 22, no. 3 (Winter, 2017/2018)

5 Nancy MacLean, Democracy in Chains: The deep history of the radical right's stealth plan for America (Penguin, 2017). 
From this "unlisted archive" she has contrived a sinister plot. Buchanan, it turns out, aided and abetted by "shadowy billionaires," most notably the Koch brothers, wanted to destroy democracy. She can now reveal "the utterly chilling story of the ideological origins of the single most powerful and least understood threat to democracy today: the attempt by the billionaire-backed radical right to undo democratic governance":

Buchanan ... argued that representative government had shown that it would destroy capitalism by fleecing the propertied class-unless constitutional reform ensured economic liberty, no matter what most voters wanted.

This single sentence captures MacLean's innocence of political economy. She doesn't understand the science.

"Representative government"-democracy-means rule by the people. But just what people? It has been known since at least the eighteenth century that if the franchise is broad in a democracy, including many poor people as well as a few rich ones, then it has a potentially fatal flaw: A broad democracy without checks and balances to protect wealthy minorities from expropriation by the state is an unstable arrangement.

American and British democracies two or three hundred years ago were not, of course "broad." For much of the time, only those with skin in the gamemen, owners of land or payers of tax-were eligible to vote. Now, however, the U.S. has a very broad democracy: there are no sex or property qualifications and voting age (18) is below the legal drinking age (21). Without checks and balances to limit total dominance by the majority the system would indeed be unstable.

There are of course many such checks in modern America, in the Constitution-federalism, the independent judiciary, a free press-but MacLean deplores them all. In MacLean's majoritarian version of democracy, the majority is a virtuous monopoly, with absolute power. She is surely aware of Lord Acton's dictum about absolute power, but Public Policy professor Maclean seems not to understand one of the most basic facts about democracy.

It is always possible, given a large enough collection of facts, to select from them just those that support a desired story. Nancy MacLean's book is in this tradition. Buchanan in his many writings and talks always emphasized at the outset that ideas were supremely important to him. His overriding motivation 
was to understand and explain (his usage) how individuals make choices and how different social arrangements affect their choices. Yes, he was a libertarian, or a "classical liberal," as he preferred to call himself. Yes, he would no doubt have liked society to be organized differently. But these desires were not the main source of his work. He admitted in one interview that a socialist society would be perfectly acceptable to him if it was the result of genuine consensus. Yet Buchanan's supposed political preferences absolutely dominate MacLean's account.

Munger's detailed critique points out the many places where MacLean has found conspiracy when Buchanan was simply advancing an intellectual movement. For comparison, he quotes MacLean's Marxist colleague Fredric Jameson, who has for many years expressed a similar objective: to create a “Marxist intelligentsia." Buchanan's half-serious aim was to create "an effective counterintelligentsia." The briefest of glances at the political preferences of social science faculty in American universities shows that Jameson has come a lot closer to achieving his goal than Buchanan. So much for the "far-flung ... intricately connected institutions funded by the Koch brothers and their now large network of fellow wealthy donors."

In his Nobel lecture, Buchanan points out the eighteenth-century discovery of Adam Smith's “invisible hand," the way that individual, self-interested choices (can) lead to collective good. Public Choice Theory, a product of work by Buchanan and his long-time collaborator Gordon Tullock, attends to "the processes through which individual choices are exercised.” This ultimately voluntary basis for political agreement runs counter to the postmodern Marxist emphasis on politics as power. Instead of being passive victims of power or oppressive exercisers of it, Public Choice sees individuals in a democracy as voluntarily obeying rules arrived at through an agreed upon process. It is an attempt to extend Smith's insight to collective action. Since claims about unfair power relations are at the heart of progressive politics, MacLean is perhaps unwilling to consider an approach that tries to understand democracy as the outcome of voluntary action by free individuals.

MacLean's book has received considerable acclaim. The first few pages are devoted to no less than twenty-seven enthusiastic endorsements. Why this enthusiasm from so many left-leaning sources? The answer is simple. First, the book is readable, well-written, and with a great plot. But more importantly, it ticks every box of the progressive checklist, taking approved positions on every 
one: capitalism, white men, selected billionaires, the "radical right," vouchers and public schools, anthropogenic global warming, Southern racism, and racial segregation. What's not to like?

In fact, the book is a footnoted docudrama of the "Based on Real Events" type, masquerading as disinterested research. It is embarrassing that such a product is apparently valued as a scholarly contribution by Duke's History and Public Policy Departments.

\section{Ideology and History of Science}

A political bias need not damage historical writing if it is presented honestly. John Desmond “Sage” Bernal (1901-1971) was a polymath Irish X-ray crystallographer and a committed communist. He was a prolific writer as well as an influential scientist who played a peripheral role in the Watson-Crick discovery of DNA. Bernal's 1,039-page four-volume Science in History ${ }^{6}$ covers the history of science, broadly defined, in a rather back-and-forth fashion from the Stone Age to the twentieth century. The book is generally well-regarded, but has been in the vanguard of a distressing trend.

Bernal certainly understood science and saw its value and its effect on society. But he saw also, perhaps too vividly, the reciprocal effect of society on science. In the preface he writes:

[L]argely owing to the impact of Marxist thought, the idea is grown that not only the means used by natural scientists in their researches but also the very guiding ideas of their theoretical approach are conditioned by the events and pressures of society.

Bernal emphasizes the effect of science on society in the early history but tends to favor the reverse for more recent times. Proceeding from what he thought of as the axioms of Marx and Engels, Bernal pronounces on various aspects of science and society. For example, "In the capitalist world the major feature of the twentieth century has been the rapid growth to complete dominance of large combines, trusts or cartels, partly commercial, partly

6 John Desmond Bernal, Science in History, $3^{\text {rd }}$ edition (London: Watts \& Co. 1965). 
industrial.” Yes, unchecked capitalism produces monopolies. We see it now not so much in heavy industry as in big tech-Facebook, Twitter, Amazon, and Alphabet-“natural” monopolies produced by huge positive feedback to scale, advantages not of production but in augmented demand. The most popular service will be most attractive and least costly to new users.

Of course communism doesn't give rise to monopolies; it doesn't need to because it is itself a monopoly. The state runs everything, which Bernal applauds, apparently unaware of the possibly insoluble information problems confronted by central state planning not to mention a centralized society devoid of checks and balances.

Bernal's belief in Marxism led him to consider it real science taking in everything from history to law. As for experimentation, which is the essence of science, the proto-communist societies of Soviet Russia, China, and Eastern Europe seemed to him just as good as the laboratory studies of Michael Faraday or Claude Bernard. This extraordinary delusion, a product of his devotion to Marxism and the Soviet “experiment," led him to support the destructive pseudo-science of Trofim Lysenko. Lysenko's failed Stalin-backed, agricultural policy led to the death of millions. Dissenting scientists lost their jobs or were imprisoned or even in some cases executed by the Stalinist regime. Bernal remained a fan anyway.

Nevertheless, Science in History is a fascinating read, full of interesting facts and speculations. Bernal understands Darwin even as he deplores one kind of Darwinism:

The simple tracing of evolutionary relationships between organisms and the building of elaborate family trees distracted naturalists from the study of the actual lives of the inner workings of animals and plants ...

Bernal didn't blame Darwin for this distraction nor for development of eugenics, the brainchild of the brilliant Francis Galton: "It was with the highest of intentions that Francis Galton, Darwin's cousin, set about studying the heredity of men of exceptional ability in Britain.” Scientists share some blame for the horrors that followed, says Bernal, since their "fear of entangling themselves in politics meant that they left the social application of their own ideas to other people, and made no effective protest against the perversion of the products of their own researches.” Thus, James-Bond-like, scientists are 
handed a license if not to kill, at least to politic. Others might see Lysenko as a textbook example of the dangers of politicized science, but his devotion to Soviet Marxism made this impossible for Bernal. Ideological commitment is not a basis for truthful history—of science or anything else.

\section{History of Science as Journalism}

Naomi Oreskes and Erik Conway's Merchants of Doubt $t^{7}$ is both a history of research on a number of hot-button topics-anthropogenic global warming (AGW), the ozone hole, acid rain, passive tobacco smoke-and an attack on dissenters such as global warming “deniers."

The book should be judged as sensationalist journalism, with accuracy and comprehensiveness as subordinate virtues. Like much journalism it embraces the genetic fallacy as a useful rhetorical tool: never mind what he says, why does he say it? Who's paying? It assumes, as many journalists do, that peer review is a guarantee of truth, rather than a weak barrier against obvious mistakesand sometimes a suppressor of dissent. The book's coverage is partial: the most prominent AGW “deniers” are elderly senior scientists. Not included are younger, more active scientists less likely to be dismissed as "past it."

As I have pointed out elsewhere the book's case against passive smoking is flawed: an important study is missed, some studies are misrepresented, and the book seems oblivious to the scientific difficulties involved in studying potentially dangerous effects that are likely to affect only a small fraction of the population and only after long delay. ${ }^{8}$ Nevertheless, it is in many ways a persuasive book.

The problem is, Naomi Oreskes is not a journalist but an academic historian of science. Has scholarly history of science now become nothing more than political journalism-with footnotes? Probably, as Oreskes discussing her most recent book happily promotes shared values as a way to get a scientific message across: "[S]cientists need to talk about the values that motivate them and shape the science they do." 9

$7 \quad$ Naomi Oreskes, Erik M. Conway, Merchants of Doubt (Bloomsbury, 2010).

8 John Staddon, "Facts vs. Passion: The debate Over Science-based Regulation," Academic Questions 33, no.1 (Spring, 2020): 101-110.

9 Naomi Oreskes, Why Trust Science? (Princeton University Press, 2019). 
Bernal would agree. I am less sure that he would agree with the book's conclusion that "[m]any scholars in the history and philosophy of science and science studies have ... recently converged on a new view . . of scientific knowledge as fundamentally consensual.” Oreskes comes perilously close to the view that if the experts agree, we must accept it as truth. Those that disagree can be dismissed as special interests or "cranks," a position somewhat at odds with her advocacy of "diversity." She is aware of the contradiction and offers this resolution: "Respecting professional diversity and lay expertise is also a different matter from heeding 'dissent' from people with no credible claim to expertise."

In any case, the diversity Oreskes wants is not viewpoint diversity but demographic diversity. No problem, as one implies the other: "demographic diversity is a proxy for perspectival diversity." Well, it isn't: not infrequently members of a group that is diverse in Oreskes's sense will be less free with their opinions than members of a more homogeneous group, out of fear of giving offense. And who will judge whether a dissenter be a "crank" or not?

History of science as an academic field has been infected by two fashionable viruses: 1 , politics, the work has to signal clearly that it is on the right (i.e. left) side. And 2, narrative, it must tell some kind of story. Never mind objectivity, it should have a good yarn. So "Sage” Bernal, who was indeed politically biased but was up-front about it, understood science and didn't try to make a novel out of it, we pass through Desmond and Moore's covert Marxism and knowing re-interpretation of Darwin's language to, finally, Oreskes and Conway, writing history so as to entertain and indict capitalism, at the expense of objectivity and true understanding. Change is needed: politics and science are different even though each influences the other. Politics with little or no real science is propaganda. "Based on real events" is not good enough. 